\title{
O ENCONTRO CONSIGO MESMO: UMA POSSÍVEL LEITURA FILOSÓFICA DO TEMA EM "O ESPELHO" DE MACHADO DE ASSIS
}

\author{
ALESSANDRA CARBONERO LIMA \\ Universidade de São Paulo \\ São Paulo, São Paulo, Brasil \\ MARCOS SIDNEI PAGOTTO-EUZEBIO \\ Universidade de São Paulo \\ São Paulo, São Paulo, Brasil
}

Resumo: Neste artigo, buscamos explorar o tema do conhecimento de si, no conto "O espelho. Esboço de uma nova teoria da alma humana" de Machado de Assis, especialmente no âmbito do desenvolvimento filosófico encontrado na imagem de Sócrates que Platão prepara na "Apologia" e em seus primeiros diálogos, o que nos leva à discussão do tema correlato, ou seja, o encontro entre mestre e discípulo.

Palavras-chave: Machado de Assis; espelho; conhecimento de si; mestre; discípulo

\section{ENCOUNTER WITH ONESELF: A POSSIBLE PHILOSOPHICAL READING OF THE THEME IN “THE MIRROR”, BY MACHADO DE ASSIS}

\begin{abstract}
In this paper, we aim at exploring the theme of the self-knowledge in the short story "The Mirror: A Sketch for a new theory of the human soul" by Machado de Assis, especially in the scope of the philosophical development found in the picture of Socrates that Plato prepares in the "A pology" and in his first dialogues, which lead us to the discussion of the correlated topic, that is, the meeting between master and disciple.
\end{abstract}

Keywords: Machado de Assis; mirror; self-knowledge; master; disciple 


\section{Sobre a possibilidade do conhecimento de si}

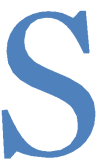

obre a possibilidade do conhecimento de si, concentremo-nos na ideia do encontro consigo mesmo. Esse encontro pode ser pensado, por um lado, como um esforço de aproximação daquilo que já se é, mas também, por outro lado, como um esforço em sentido contrário, isto é, como afastamento de si.

Na Odisseia, por exemplo, Telêmaco é um jovem doce, resignado diante da insolência dos pretendentes de sua mãe e incapaz de defender energicamente seus direitos. Ele cresce sem o amparo paterno e, portanto, neste caso, sem referência a um paradigma de excelência. É preciso que Atena, primeiro transfigurada em Mentes e, adiante, em Mentor, faça as vezes do conselheiro amigo e do mestre e o admoeste a tornar-se quem já é, no coração. Ele deixa a terra natal em busca de notícias do pai. Nessa viagem, deixa de ser um jovem inexperiente para se fortalecer na busca heroica de sua identidade. Esta seria finalmente encontrada junto da figura paterna, no episódio da matança dos pretendentes. Então, nesse reencontro, Telêmaco aparece, cônscio de seu valor, confiante na qualidade de sua ação. É agora o companheiro de armas, resoluto e audacioso.

No Édipo rei, de Sófocles, é preciso purificar Tebas da mácula de um crime de sangue; por isso, há que se identificar o assassino de Laio. Determinado, Édipo põe-se a investigar. Nada o impede. Segue irredutível em seu intento, para descobrir ser ele próprio a quem procurava. Édipo reconhece-se, enfim, como quem já é. Ele já é o assassino do pai e o esposo da mãe.

$\mathrm{Na}$ Apologia platônica, outro não é o sentido da tarefa filosóficopedagógica que Sócrates se impõe. Nesse texto, Sócrates é dos homens o mais sábio - diz o deus que habita o oráculo de Delfos. Ora, a divindade não mente. Resta compreender o significado de suas palavras. Eis a missão socrática. Para tanto, sabemos, Sócrates se lança a uma atividade específica, que chamará de filosofia. Questiona os mais sábios de seu tempo sobre temas variados. Percebe que esses homens estavam equivocados quanto ao que supunham saber. Sócrates descobre que sua sabedoria consiste na plena consciência de que sabe o que os demais não sabem, isto é, que nada sabe. E o que se vê aí? Outra vez, um esforço de investigação em torno de si. A divindade já nos revelara Sócrates. Não basta. É preciso que Sócrates se revele a si mesmo.

Mas não seria o encontro consigo mesmo um encontro com o outro que habita em nós? No conto "O outro", Jorge Luis Borges figura um encontro 
consigo mesmo. No encontro fantástico, um Borges por volta dos setenta anos se põe a conversar com um outro, que é ele próprio, uma sua versão que ainda não alcançara os vinte anos. O Borges de setenta anos sabe-se o de vinte anos, mas o estranha. Esse outro que Borges sabe ser ele é de fato ele, mas é também outro, completamente o outro ou completamente um outro.

O tema do conhecimento de si não escapou também a Machado de Assis. Memórias póstumas de Brás Cubas pode ser lido como uma análise minuciosa de si. Mas de um si que não existe mais, de um si que é o outro de um eu tornado, pela morte, pura consciência. Ou puro conhecimento. $\mathrm{O}$ eu que fala, destituído da vida, está livre do espetáculo, livre da plateia. Pode confessar "o que foi e o que deixou de ser", como aparece no capítulo XXIV:

Talvez espante ao leitor a franqueza com que lhe exponho e realço a minha mediocridade; advirta que a franqueza é a primeira virtude de um defunto. Na vida, o olhar da opinião, o contraste dos interesses, a luta das cobiças obrigam a gente a calar os trapos velhos, a disfarçar os rasgões e os remendos, a não estender ao mundo as revelações que faz à consciência; e o melhor da obrigação é quando, à força de embaçar os outros, embaça-se um homem a si mesmo, porque em tal caso poupa-se o vexame, que é uma sensação penosa, e a hipocrisia, que é um vício hediondo. Mas, na morte, que diferença! que desabafo! que liberdade! Como a gente pode sacudir fora a capa, deitar ao fosso as lantejoulas, despregar-se, despintar-se, desafeitar-se, confessar lisamente o que foi e o que deixou de ser! ${ }^{1}$

Mas não enveredaremos pelo caminho do romance. Antes, elegemos o conto. Em "O espelho. Esboço de uma nova teoria da alma humana", identificamos o mesmo tema do encontro consigo mesmo. Mas enunciado de uma maneira nova e teórica, como o subtítulo parece indicar. E, ainda como sugere o subtítulo, não de maneira acabada, mas como um esboço, o que enseja conjecturas de diversas ordens.

${ }^{1}$ ASSIS, Memórias póstumas de Brás Cubas, p. 27-28. 


\section{A busca de si diante do espelho}

O conto se inicia com um Jacobina entre quarenta e cinquenta anos, "provinciano, capitalista, inteligente, não sem instrução", 2 um sujeito astuto e cáustico, que não discutia nunca, mas que acompanhava quatro amigos que discutiam calorosamente sobre coisas metafísicas. Em dado momento, Jacobina alude a uma sua experiência da juventude que lhe revela a natureza da alma humana. Metafisicamente, esclarece Jacobina, o homem é como uma laranja, possui duas partes ou, mais especificamente, duas almas, uma interior e outra exterior, e esta, ademais, muda de forma.

Cada criatura humana traz duas almas consigo: uma que olha de dentro para fora, outra que olha de fora para dentro [...]. A alma exterior pode ser um espírito, um fluido, um homem, muitos homens, um objeto, uma operação. Há casos, por exemplo, em que um simples botão de camisa é a alma exterior de uma pessoa; - e assim também a polca, o voltarete, um livro, uma máquina, um par de botas, uma cavatina, um tambor etc. Está claro que o ofício dessa segunda alma é transmitir a vida, como a primeira; as duas completam o homem, que é, metafisicamente falando, uma laranja. ${ }^{3}$

E não é sem complexidade que essas partes que compõem o todo se relacionam. "Quem perde uma das metades, perde naturalmente metade da existência; e casos há, não raros, em que a perda da alma exterior implica a da existência inteira." ${ }^{4}$

Há, então, que demonstrar a teoria. Nesse sentido, segue-se o episódio ilustrativo da juventude de Jacobina. Aí, lê-se a história de um Jacobina pobre, aos vinte e cinco anos, recém-nomeado alferes da guarda nacional. A nomeação causara desgosto aos concorrentes. Mas agradara à mãe, que o tomava, agora, por seu alferes, e agradara à tia, d. Marcolina, que, desejosa do sobrinho, recebe-o, com farda e tudo, no sítio "escuso e solitário"5 onde morava, a muitas léguas da vila. Ali, junto da tia Marcolina, Jacobina era também o alferes.

E sempre alferes; era alferes para cá, alferes para lá, alferes a toda a hora. Eu pedia-lhe que me chamasse Joãozinho, como dantes; e ela abanava a

\footnotetext{
2 ASSIS, "O espelho", p. 21.

3 Idem, p. 22.

${ }^{4}$ Ibidem.

${ }^{5}$ Idem, p. 23.
} 
cabeça, bradando que não, que era o "senhor alferes". Um cunhado dela [...] que ali morava, não me chamava de outra maneira. Era o "senhor alferes", não por gracejo, mas a sério, e à vista dos escravos, que naturalmente foram pelo mesmo caminho. ${ }^{6}$

No sítio da tia, Jacobina ocupava o melhor lugar à mesa e era, em primeiro, servido. Os mimos se completam com uma deferência especial: o espelho, grande, que a tia recebera da madrinha, herdado da mãe, que o comprara "a uma das fidalgas vindas em 1808 com a corte de d. João VI", "obra rica e magnífica, que destoava do resto da casa, cuja mobília era modesta e simples", 8 já muito velho, mas no qual ainda se via "o ouro, comido em parte pelo tempo, uns delfins esculpidos nos ângulos superiores da moldura, uns enfeites de madrepérola e outros caprichos do artista". 9 Durante a estadia de Jacobina, estava decidido: o espelho, a melhor peça da casa, ficaria alocado em seu quarto. Porém, todas essas coisas, carinhos, atenções, obséquios, operam em Jacobina uma séria transformação:

$O$ alferes eliminou o homem. Durante alguns dias as duas naturezas equilibraram-se; mas não tardou que a primitiva cedesse à outra; ficoume uma parte mínima de humanidade. Aconteceu então que a alma exterior, que era dantes o sol, o ar, o campo, os olhos das moças, mudou de natureza, e passou a ser a cortesia e os rapapés da casa, tudo o que me falava do posto, nada do que me falava do homem. A única parte do cidadão que ficou comigo foi aquela que entendia com o exercício da patente; a outra dispersou-se no ar e no passado. ${ }^{10}$

Jacobina torna-se, enfim, exclusivamente alferes, exclusivamente a alma exterior que se lhe apresentava. Eis os fatos. A consciência da transformação será precipitada por uma grave notícia. Uma das filhas da tia adoecera; a morte se avizinhava. A tia teve de partir e, ao fazê-lo, levou junto o cunhado. A Jacobina coube a tarefa de tomar conta do sítio. Restava-lhe, apenas, então, a companhia dos escravos que, como a tia e o cunhado, revezavam-se nos agrados. Nesse caso, contudo, a motivação dos agrados era claramente o engodo. $\mathrm{Na}$ manhã seguinte à partida da tia, Jacobina amanhece só. Durante a noite, os escravos fugiram. Desperta diante de um

\footnotetext{
${ }^{6}$ Idem, p. 24, grifos nossos.

${ }^{7}$ Ibidem.

${ }^{8}$ Ibidem.

${ }^{9}$ Ibidem.

${ }^{10}$ Idem, p. 24-25, grifos nossos.
} 
"terreiro deserto e da roça abandonada", ${ }^{11}$ na companhia dos galos e das galinhas, de um par de mulas e de três bois. Era isso. Nenhum ente humano a lembrar-lhe quem era. Na ausência dos parentes e dos escravos, a alma exterior lhe escapava:

Tinha uma sensação inexplicável. Era como um defunto andando, um sonâmbulo, um boneco mecânico. Dormindo, era outra coisa. O sono dava-me alívio [...] eliminando a necessidade de uma alma exterior, deixava atuar a alma interior. Nos sonhos, fardava-me orgulhosamente, no meio da família e dos amigos, que me elogiavam o garbo, que me chamavamalferes; vinha um amigo de nossa casa, e prometia-me o posto de tenente, outro o de capitão ou major; e tudo isso fazia-me viver. Mas quando acordava, dia claro, esvaía-se com o sono a consciência do meu ser novo e único porque a alma interior perdia a ação exclusiva, e ficava dependente da outra, que teimava em não tornar... Não tornava. ${ }^{12}$

Oprimido por um silêncio avassalador, Jacobina mal comia. Consumia-se na espera da parte da alma que teimava em não regressar. Tentou lhe dar nova forma. "Recitava versos, discursos, trechos latinos, liras de Gonzaga, oitavas de Camões, décimas, uma antologia em trinta

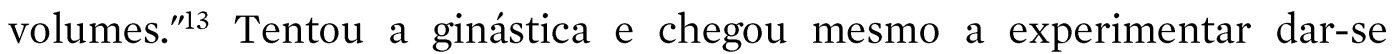
beliscões nas pernas. Nada acontecia. Vinham-lhe o cansaço, a dor. Mas a alma externa, decerto, evadira-se. Lembrou-se, enfim, do espelho, o qual ignorara por oito dias. Nele, contudo, para seu espanto, também já não podia ver-se. Na solidão, as leis da física ausentaram-se e, no espelho, Jacobina percebia apenas uma sombra de si, uma vaga, esfumada e difusa figura. Eis que uma ideia o salva. Lembra-se de vestir a farda de alferes. Fardado, diante do espelho, vê agora uma figura nítida e inteira.

Quem é Jacobina, afinal? Diferentemente de Sócrates e de Édipo, Jacobina não se põe a investigar quem é. O conhecimento de si se lhe apresenta de súbito. Jacobina não é aí senão o que o espelho lhe revela, no caso, o alferes. Para além do alferes, para além do que os outros nele veem, não há nada. Jacobina vê no espelho o papel social desempenhado, nada mais, nada menos. De fato, o espelho não reflete a natureza essencial, imutável, de Jacobina. Uma tal coisa não existe. Somos o que temos sido aos

\footnotetext{
${ }^{11}$ Idem, p. 26.

12 Idem, p. 27, grifos nossos.

${ }^{13}$ Ibidem.
} 
olhos dos outros, é o que sugere a teoria da alma de Jacobina. Aí, encontrar a si é afastar-se de si, ou melhor, da possibilidade do si mesmo.

Nesse sentido, não cabe aproximar o conto machadiano do pensamento socrático-platônico. Sócrates, em Platão, parece convicto de que há um si mesmo a ser conhecido. No entanto, consideremos uma possível identidade de forma. Encontrar a si mesmo não seria necessariamente encontrar um outro? Na Apologia, ao final de sua investigação, Sócrates encontra um outro que não sabia ser, o mais sábio dos homens. É necessária a intervenção do deus, lembremos. Na sentença do deus, Sócrates é apresentado a um outro, um outro que não é senão Sócrates. No caso de Édipo, a investigação, que só pode se resolver com o apoio de Tirésias, também revela um outro, um outro que Édipo vinha sendo sem saber. No conto borgiano, Borges é também aquele outro que ele lembra ter sido. Nos outros, Jacobina encontra um outro, aquele que passou a ser diante do novo papel social. Antes, o filho, o sobrinho; agora, o alferes. Jacobina reconhece a si mesmo ao reconhecer um outro, ainda que, aqui, eventualmente, este outro, o alferes, seja tudo o que tem sido Jacobina.

\section{O encontro consigo}

Em todos os casos, ainda, o encontro consigo mesmo pressupõe sempre um outro. É a lição do Primeiro Alcibíades, de Platão. O texto explora o tema da formação do governante e do homem excelente e, nele, o Sócrates platônico quer fazer ver um jovem Alcibíades que a educação do governante deve envolver também um esforço de aperfeiçoamento de si em direção à virtude. No entanto, esse esforço de aperfeiçoamento de si, que corresponderá ao cuidado da alma, para tornar-se factível exige que conheçamos o objeto que se quer aperfeiçoar, no caso, o si-mesmo, que aí será identificado à alma, ${ }^{14}$ aparentemente una, cuja versão tripartida conhecemos especialmente pela República. Mas, no diálogo, interessa-nos sobretudo o modo como alcançamos a nós mesmos ou, se se quiser, como alcançamos o conhecimento perfeito da alma. Esse acesso se dá invariavelmente por interposta pessoa. Por isso, sozinho, Alcibíades não pode alcançar a si mesmo e, então, colocar-se a se aperfeiçoar. É preciso um intermediário, para cuja tarefa Sócrates se apresenta. ${ }^{15}$ É ele notadamente aí

14 Platão. Primeiro Alcibíades, 130a-c.

${ }^{15}$ Idem, $124 \mathrm{~d}$. 
o mestre que quer bloquear o caminho. Alcibíades não pode seguir em seu intento de administrar a cidade de Atenas se, antes, não alterar a rota; se, antes, não for outro; se, antes, não se tornar o que já é, isto é, se, antes, não encontrar a si mesmo.

A ideia parece se esclarecer com a metáfora da visão. Nesses passos, o Sócrates platônico pretende explicar o significado que atribui ao conhecido preceito délfico Conhece-te a ti mesmo. Busca por um termo de comparação. Encontra-o na visão. Sócrates sugere tomarmos os olhos por pessoas. Se assim o fizéssemos, o recurso de que disporiam os olhos para o conhecimento de si seria o que lhes é próprio, a visão. Para o conhecimento de si, restaria aos olhos procurar um objeto no qual pudessem ver a si próprios. Esse objeto, Alcibíades pensa ser o espelho. Mas Sócrates tem outro objeto em mente. ${ }^{16}$ Vemo-nos refletidos nos olhos de quem nos olha.

Sócrates - Como já deves ter observado, o rosto de quem olha para os olhos de alguém que se lhe defronte, reflete-se no que denominamos pupila, como num espelho a imagem da pessoa que olha. ${ }^{17}$

E:

Sócrates - Assim, quando um olho olha para outro e se fixa na porção mais excelente deste, justamente aquele que vê, ele vê-se a si mesmo? ${ }^{18}$

Ora, é no outro que a nós nos encontramos. Vemo-nos na medida em que somos vistos. Conhecemo-nos na medida em que um outro nos dá a conhecer a nós mesmos. Telêmaco não pode tornar-se quem é sem a admoestação de Atena; Édipo dependerá da orientação de Tirésias para encontrar o caminho que conduzirá à sua identidade; Sócrates encontra na divindade esse outro que nos revela a nós mesmos; Borges nota-se já outro por meio de seu duplo; Jacobina torna-se inteiro, por isso, quem de fato é, no espelho que lhe reflete um outro.

$\mathrm{E}$, aqui, desse modo, nos aproximamos do tema do encontro entre o mestre e o discípulo. Esse encontro, é possível entendê-lo referido a um encontro, antes, consigo mesmo. Consideremos uma imagem, uma das que encontramos nesse grande conjunto de estórias e anedotas sobre os sábios e filósofos da Antiguidade que são as Vidas dos filósofos ilustres, de Diógenes

\footnotetext{
${ }^{16} \mathrm{Idem}, 132 \mathrm{~d}$.

${ }^{17}$ Idem, 132e-133a. Para o Primeiro Alcibíades, usamos a tradução de Carlos Alberto Nunes.

${ }^{18}$ Idem, 133a.
} 
Laércio. A cena está no segundo livro das Vidas e nos mostra o encontro de um discípulo (que não sabe ainda que é ou será um discípulo) com seu mestre. Um jovem, belo e modesto ateniense caminha em direção ao seu destino.

Xenofonte era filho de Grilo, ateniense, do demo de Érquia; modesto e muito bonito.

Conta-se que ele andava em uma via estreita e Sócrates estendeu seu bastão e o impediu de seguir.

Aprendeste onde se vendem alimentos de todo tipo? [perguntou Sócrates]

[Xenofonte] respondeu de volta que aprendera.

E onde é que os homens se tornam excelentes? [perguntou Sócrates]

[Xenofonte] ficou perplexo.

Segue-me, então, disse [Sócrates], e aprende. ${ }^{19}$

Xenofonte, esse personagem dificilmente classificável, como outros de seu tempo, que escreverá manuais de caça, livros de História, uma explanação acerca da forma como o rei Ciro da Pérsia foi educado (para uso dos que quisessem conhecer uma boa educação) e tantas outras obras, e que nos dará também as Memoráveis ou lembranças de Sócrates, nasce, por assim dizer, como discípulo de maneira abrupta e inesperada. De repente.

Olhemos com mais cuidado o cenário. Há uma via estreita, lugar sempre perigoso, pelo risco constante de se ter bloqueado o caminho ou a fuga. ${ }^{20}$ Quem o bloqueia, no entanto, não é um criminoso, não é um ladrão. ${ }^{21}$ O caminho estreito pelo qual Xenofonte seguia ao deparar-se com Sócrates, se pudermos pensar assim, era já o caminho difícil ou ao menos o caminho arriscado do encontro consigo mesmo, que tem no encontro com o mestre, que o impede de prosseguir, uma exigência. Impedimento que é duplo: o bastão impede que Xenofonte continue a desapercebida caminhada, e o corpo para, diante do bastão. Mas há o impedimento também do

\footnotetext{
${ }^{19}$ DIÓGENES DE LAÉRCIO. Vida dos filósofos ilustres, II, 6, p. 48, tradução nossa.

${ }^{20}$ A imagem do caminho estreito como sinal da rota para a virtude nós vamos encontrar, curiosamente, nas Memoráveis do próprio Xenofonte, quando o sofista Pródico coloca o herói Hércules diante de uma encruzilhada de dois caminhos, um largo e o outro estreito, um levando para uma vida de vícios com seu complemento de infelicidade, outro levando para a virtude de ser dono de si mesmo, a enkráteia, virtude fundamental do núcleo ético do retrato socrático de Xenofonte, tão cara à vertente antistênica ou cínica do socratismo. Cf. XENOFONTE, Memoráveis, II, 1, p. 22-34.

${ }^{21} \mathrm{Ou}$ talvez o seja, de certa maneira: Sócrates encanta os que dele se aproximam a ponto de se esquecerem de si mesmos, ressalta o Alcibíades do Banquete platônico, reclamando dessa "usurpação de si" causada por Sócrates. PLATÃO, Banquete, 215 e 216b.
} 
pensamento. E o que bloqueia o pensamento de Xenofonte, e o obriga a voltar-se sobre si mesmo é um, digamos, bastão mental, um entrave para o intelecto.

Propõe Sócrates um enigma, fantasiado, no entanto, da banalidade comum a tantas das perguntas que fazia. A primeira pergunta trivial, sobre o lugar em que se vendem os alimentos, é respondida com a certeza dos ingênuos. Mas a segunda, a que deseja saber onde ou como se tornam os homens excelentes (kaloi kagathoi), essa pergunta Xenofonte não sabe, ou, melhor dizendo, sobre isso ele nada aprendeu. Talvez não tenha mesmo, alguma vez, se ocupado em conceber como pergunta a forma como se pode chegar a ser um homem excelente. Perceber que não se sabe, aqui, é o início da sabedoria. Desde então, Xenofonte passa a seguir Sócrates, esse que, sem aviso para o discípulo que ainda não se sabe discípulo, bloqueia duplamente seu caminho, cria um impedimento que não se pode disfarçar e obriga a mudança de rota. Esse encontro muda a vida de Xenofonte para sempre. ${ }^{22}$

O obstáculo que o mestre, esse outro, aí representa é aquele que conduz a uma espécie de arriscada viagem de autodescoberta. Essa ideia é amplamente desenvolvida em Professores para quê?, de Georges Gusdorf. Nesse horizonte, em relação ao discípulo, o acaso desse encontro é entendido como ocasião privilegiada para o despertar de uma "mais autêntica consciência de si". $^{23}$ Reconhecer um mestre será assim reconhecer uma demanda antes mal percebida, a vocação que não se notava, a certeza de um destino. Deparar-se com um mestre será então também aceitar uma súbita mudança de rumo e "a nova obrigação de procurar a plena realização na perspectiva bruscamente descoberta". ${ }^{24}$ Nesse sentido, o mestre é o que impede. Impede-nos, contudo, o caminho conhecido, para exigir-nos a rota do exame de si, em direção a esse que habita em nós.

Encontrar o mestre que nos cabe é, por isso, no outro, encontrar a si próprio, ainda que esse espelho, que é o outro, ao fim, talvez só possa de fato nos apresentar um outro que temos sido. Borges no encontro com o duplo é já outro. Jacobina é necessariamente também um outro. Mas, mesmo nos casos de Telêmaco, Édipo e Sócrates, o eu que se mostra é ainda um outro, um outro que já se é sem saber, um outro que é imperioso nos tornarmos.

Por isso, é importante recordar que, embora "O espelho" se encerre com a autodescoberta de Jacobina, de que sua identidade é dependente do

\footnotetext{
${ }^{22}$ Encontro bem retratado em um parágrafo de Professores para quê?. Cf. GUSDORF, Professores para quê?, p. 95-96.

${ }^{23}$ Idem, p. 95.

${ }^{24}$ Idem, p. 100.
} 
olhar do outro, não estamos mais diante do Jacobina de vinte e tantos anos, mas da reflexão de um homem que passou dos quarenta, que não é mais alferes e sim capitalista.

Jacobina não se apresenta como um teórico que explica sua nova teoria, que é tão somente esboçada na explicação inicial que dá sobre as duas almas, a que olha de dentro para fora e a que olha de fora para dentro, mas é um mestre que ensina pelo exemplo, pela narrativa, pelo testemunho de sua descoberta.

Jacobina se predispõe a ensinar o que, para ser aprendido, teve de ser vivido: uma experiência psicologicamente trágica. Seu processo de descoberta ocorre quando o real se apresenta cruamente, despido de qualquer referência, de qualquer sentido, marcado por um tempo que, ao passar, não traz nem leva, apenas se dilui na imobilidade. Isolado, Jacobina vê, a um só tempo, que o real é insignificante e ele próprio não é nada, nem alferes, nem o jovem de antes, nem o sobrinho da tia Marcolina, absolutamente nada. Seu corpo está lá, sua mente procura ocupar-se, mas o sentido desapareceu, sua alma desapareceu, destituída de vontade, de referência, de ânimo. [...] Sem referência, sem público, sem o social, todas as convenções anulam-se, sua alma não tem onde se espelhar.

[...] a alma humana depende da opinião dos outros para se afirmar, ou seja, depende da sociedade e de seus valores, mas esses mesmos valores não brotam do nada, uma vez que estão subjugados ao acaso das convenções que os formam; dependem, portanto, da(s) alma(s) humana(s). A alma cria os valores sociais que a criam. Ou: os valores sociais criam a alma que os cria. ${ }^{25}$

A experiência de Jacobina aponta não só para a transformação de sua alma exterior pregressa, o outro que deixou de ser o Joãozinho para se tornar o Senhor Alferes, mas também para o devir, o outro que viria a se tornar. É possível, portanto, afirmar que o Jacobina capitalista já estava no Jacobina Alferes, como um outro de si, assim como conjecturou Dom Casmurro, quando encerrou seu livro indagando "se a Capitu da praia da Glória já estava dentro da de Matacavalos". ${ }^{26} \mathrm{O}$ que de fato não temos como afirmar é se Jacobina tornou-se Jacobina por ter aprendido a lição do espelho, ou se aprendeu a lição do espelho por ser Jacobina.

${ }^{25}$ ALMEIDA, Rogério de. O imaginário trágico de Machado de Assis: elementos para uma pedagogia da escolha, p. 123-124.

${ }^{26}$ ASSIS, Dom Casmurro, p. 183. 
Entretanto, assumida a hipótese de que um Jacobina estava dentro do outro, aceita a conjectura de que podemos nos tornar nós mesmos, só nos restaria concluir pela dimensão educativa da investigação de si. A possibilidade do conhecimento de si não seria, então, a assimilação de uma verdade ensinada, mas um encontro consigo mesmo, saber da experiência vivida, mas que para ser vivida precisa do outro. Ou do espelho.

\section{Referências}

ALMEIDA, Rogério de. O imaginário trágico de Machado de Assis: elementos para uma pedagogia da escolha. São Paulo: Képos, 2015.

ASSIS, Machado de. Dom Casmurro. 28. ed. São Paulo: Ática, 1994.

O O espelho. São Paulo: Klick Editora, 1977.
Memórias póstumas de Brás Cubas. Belo Horizonte; São Paulo: Autêntica, 2012.

BARROS, Gilda Naécia Maciel de. O espelho, de Machado de Assis, ou: Sobre o problema da identidade do homem. In: LAUAND, Jean (org.). Mirandum, ano V, n. 11, p. 31-40, 2001.

BORGES, Jorge Luis. Obras completas de Jorge Luis Borges. São Paulo: Globo, 1999.

DIÓGENES DE LAÉRCIO. Lives of Eminent Philosophers. Tradução de R. D. Hicks. Cambridge; London: Harvard University Press, 1991.

GUSDORF, George. Professores para quê? Lisboa: Moraes Editora, 1970.

HOMERO. Odisseia. Tradução de Manuel Odorico Mendes. São Paulo: Martin Claret, 2007.

PLATÃo. Defesa de Sócrates. Tradução de Jaime Bruna. São Paulo: Abril Cultural, 1972.

Primeiro Alcibíades. Tradução de Mário da Gama Kury. 2. ed. rev. Belém, Pará: EDUFPA, 2007.

SÓFOCLES. Édipo Rei. Tradução de Mário da Gama Kury. 8. ed. Rio de Janeiro: Zahar, 1998.

XENOFOnTE. Memoráveis. Tradução de Ana Elias Pinheiro. Coimbra: Centro de Estudos Clássicos e Humanísticos, 2008. 
ALESSANDRA CARBONERO LIMA é professora de Filosofia da Educação da Faculdade de Educação da Universidade de São Paulo. Bacharel em Direito, pela Faculdade de Direito de São Bernardo do Campo (FD-SBC), mestre e doutora em Educação, pela Faculdade de Educação da USP. Publicações recentes: "A lição dos antigos" (In: Nós, os antigos. São Paulo, Képos, 2014, p. 11-20); "O tirano infeliz de Xenofonte" (In: Memória clássica. São Paulo, Editora Laços, Selo Képos, 2015, p. 73-92); "Educating Rita ou sobre as possibilidades de autodeterminação". (In: Antiguidades contemporâneas. São Paulo: FEUSP/Galatea, 2016, p. 84-95). E-mail: seneca@usp.br.

MARCOS SIDNEI PAGOTTO-EUZEBIO é professor de Filosofia da Educação da Faculdade de Educação da Universidade de São Paulo. Graduado em Filosofia pela FFLCH-USP, mestre e doutor em Educação pela Faculdade de Educação da USP-FEUSP. Publicações recentes: "Philosophia, Comunicação e Paideia". (In: Memória clássica. São Paulo: Editora Laços, Selo Képos, 2015, p. 57-72); "Isócrates, filósofo da Paideia" (In: Filosofia e educação: ensaios sobre autores clássicos. São Carlos: EdUFSCar, 2014, p. 3344); "Por que ler os clássicos?" (In: Nós, os antigos. São Paulo: Editora Laços, Selo Képos, 2014,v. 1, p. 65-74). E-mail: hipias@usp.br.

Recebido: 05.05 .16

Aprovado: 04.07.16 